\title{
Response of patients with chronic Hepatitis B in one year of treatment with Major Autohemotherapy
}

\author{
Javier Cespedes-Suarez, Yanisley Martin-Serrano, Maria Rosa Carballosa-Peña, Diana Rosa Dager- \\ Carballosa
}

Cardiozono Medical Center. Luanda, Angola

\section{ABSTRACT}

\section{OPEN ACCESS}

\section{Citation}

Cespedes-Suarez J, Martin-Serrano Y, Carballosa-Peña MR, Dager-Carballosa DR. Response of patients with chronic Hepatitis B in one year of treatment with Major Autohemotherapy. J Ozone Ther. 2018:2(3)

doi: 10.7203/jo3t.2.3.2018.11459

\section{Academic Editor}

Jose Baeza-Noci,

School of Medicine, Valencia University, SPAIN

\section{Editor}

World Federation of Ozone Therapy, Bologna, ITALY

\section{Received}

February 1, 2018

\section{Accepted}

February 16, 2018

\section{Published}

December 15, 2018

\section{Intellectual Property}

Cespedes-Suarez J.

This is an open access article distributed under the terms of the Creative Commons Attribution License (CC BY 4.0), which permits unrestricted use, distribution, and reproduction in any medium, provided the original author and source are credited.

\section{Author Information docj09@gmail.com}

Hepatitis B (HVB) is one of the most common infectious diseases in the world. Its wide geographical distribution is a health problem, especially on the African continent, with prevalence rate of $6.1 \%$ in the adult population. Current treatment requires prolonged therapy (most cases for the rest of life) with the aim of stopping viral replication, maintaining immunological stability, preventing progression of liver disease and the most feared complications such as cirrhosis and hepatic cancer.

There are multiple references for ozone therapy as an alternative in the treatment of Hepatitis B, because of the known and demonstrated antimicrobial and immune modulatory properties. With these promises, we performed the present clinical study that included 28 patients with positive diagnosis of chronic Hepatitis $B$, surface antigen (HVBs Ag) positive, antibodies against surface antigen (HVBs) negative, viral load (HVB DNA) and transaminases elevated. These patients with 1 year of evolution and antiviral treatment were treated with major autohemotherapy with protocol of 15 sessions and maintenance every 15 days with an ozone concentration of $50 \mu \mathrm{g} / \mathrm{ml}$, with an initial dose of $4,000 \mu \mathrm{g}$ up to $12,000 \mu \mathrm{g}$.

We indicate Ag HVBs, Ac HVBs, HVB Viral Loading and transaminases before starting treatment, at 15 days of completion and quarterly until the year. The results showed negative of HBsAb tests from, a positive antiHBsAb test (Hepatitis B surface antibody), significant decrease of viral load to undetectable values and normal values of the transaminases demonstrating the functional recovery of the disease, associated with favorable immunological response, providing a better quality of patients' lives.

Keywords: Hepatitis B, Transaminases, Ozone therapy, Major Autohemotherapy, Surface antigen, Surface Antigen Antibody.

\section{Introduction}

Hepatitis B is a liver infectious disease caused by Hepatitis B virus (HBV), which belongs to the family Hepadnaviridae (hepatotropic DNA virus) and is characterized by hepatocellular necrosis and inflammation [1].

The development of serological tests for the different antigens and their respective antibodies has revealed the worldwide distribution of HBV, with extremely high infection rates. It is estimated that one-third of the world's 
population, 2,000 million people have been infected by HBV, and of these, about 350-400 million are chronic carriers. By 2015, 257 million people were living with chronic infection, mainly affecting the African and Western Pacific Region. Most of the deaths were due to chronic liver disease $(720,000$ cirrhosis) and primary liver cancer $(470,000$ hepatocellular carcinoma deaths) $[2,3,4,5]$.

There are now many reasons to approach the treatment of chronic hepatitis from an etiological point of view, on the evidence that the evolution depends on causative agent, replicative state, activity degree and the disease stage.

The treatment of chronic liver injury by $B$ virus is based on the etiopathogenic mechanisms that produce it, on the demonstration of the noncytopathic effect of HBV and, therefore, on its origin due to an immune specific reaction of the host mediated by activated cytotoxic $T$ lymphocytes [6].

With the development of medicine, antiviral treatment has improved the prognosis of the disease and the quality of life of those affected. However, there are also other natural treatments that perfectly complement the pharmacological ones. Ozone therapy has become a useful therapy for the treatment of many pathological processes such as hepatitis, probably due to the viral inactivation by generated endoperoxides, as well as stimulation of cytokines release. Medical ozone has antibacterial, antifungal and antivirus effect. Ozone through its active metabolite is able to modulate the immunological system in order to eliminate the virus $[7,8]$.

Several scientific studies have postulated Ozone as an excellent modulator of the immune system and its contribution to the recovery of viral diseases such as hepatitis $B$, particularly by the effects on monocytes and $T$ lymphocytes, in addition to which the production of accompanied cytokines is stimulated of an improvement of the oxygenation and the metabolism.

The action of ozone on the immune cell is compared with the effect caused by mitogens. In cytokinetic induction of immunocompetent cells, CD4 + T lymphocytes (helpers) activated by macrophages produce cytokines that initiate intercellular communication in their role as messengers. IL-2, released by these cells, is responsible for the activation and differentiation of T cell and natural killer cells (NK) cells (spontaneous cytotoxic), to induce the cytotoxicity of CD8 + T lymphocytes and to promote activation and proliferation of $\mathrm{B}$ lymphocytes, hence these cells are considered a fundamental pillar in the cell-mediated immune response [9].

Thus, CD4 + T lymphocytes, CD8 + T lymphocytes, macrophages, neutrophils, eosinophils, NK cells and the activation of antibody-dependent cellular cytotoxicity (ADCC) are immune effector mechanisms to kill cells infected by viruses, neoplastic cells or eliminate bacteria and parasites $[9,10]$.

Another interesting aspect of ozone as an immunomodulator is during the controlled "micro-oxidation" that occurs after administration, the "vaccine effect", which gives a favorable activation of antioxidant systems [11].

Given the widely recognized immune stimulatory effect of ozone therapy, the aim of this study is to determine the effectiveness of increased doses of major autohemotherapy on the humoral, immunological and biochemical response of chronic hepatitis $B$ patients receiving also antiviral treatment. 


\section{Materials and methods}

A retrospective longitudinal study was performed at the Cardiozono Medical Center located in Luanda, Angola. Twenty-eight adult patients of both sexes, who started treatment at the Medical Center in June 2016 until June 2017, were referred from our Gastroenterology office / Infectology consult and other Hospitals, diagnosed of chronic hepatitis B of one year of evolution.

Inclusion criteria: Patients with surface antigen (HBs) positive, antibodies against surface antigen (Anti-HBs) negative, viral load (HVB DNA) and Glutamic Pyruvic Transaminase (TGP), as well as Glutamic Oxaloacetic Transaminase (TGO) elevated with retroviral treatment in 1 year of evolution.

Exclusion criteria: Pregnant women, patients with other chronic diseases, autoimmune diseases, degenerative diseases, as well as patients with coagulation disorder

Treatment Protocol: The patients received 15 sessions of major autohemotherapy (one daily session). In each session we used a Germanmade Promedic Humazon equipment (Humares $\mathrm{GmbH}$, Bruchsal, Germany), 3-way stopcock, epicranial needle $19 \mathrm{G}$, Sangiset (Humares $\mathrm{GmbH}$, Bruchsal, Germany) with capacity of $350 \mathrm{~mL}$ where we put $10 \mathrm{~mL}$ of $3.13 \%$ sodium citrate to avoid blood clot during the procedure and other disposable material.

The major autohemotherapy (Table 1) was performed at a concentration of $50 \mu \mathrm{g} / \mathrm{mL}$ in $100 \mathrm{~m}$ of blood; the initial dose of the therapy was $4000 \mu \mathrm{g}(80$ $\mathrm{mL}$ of ozone gas at $50 \mu \mathrm{g} / \mathrm{mL}$ concentration); we increased the dose by 2000 $\mu \mathrm{g}$ every 2 days until reaching a dose of $12,000 \mu \mathrm{g}(240 \mathrm{~mL}$ of ozone gas at $50 \mu \mathrm{g} / \mathrm{mL}$ concentration), maintaining this dose as a maintenance dose every 15 days throughout the year.

Table 1. Treatment protocol.

\begin{tabular}{cc}
\hline Days of treatment & $\begin{array}{c}\text { O3 dose in } 100 \mathrm{ml} \text { of blood } \\
(\text { O3 concentration and volume })\end{array}$ \\
\hline Days 1-2 & $4,000 \mu \mathrm{g}(50 \mu \mathrm{g} / \mathrm{mL}$ and $80 \mathrm{ml})$ \\
Days 3-4 & $6,000 \mu \mathrm{g}(50 \mu \mathrm{g} / \mathrm{mL}$ and $120 \mathrm{ml})$ \\
Days 5-6 & $8,000 \mu \mathrm{g}(50 \mu \mathrm{g} / \mathrm{mL}$ and $160 \mathrm{ml})$ \\
Days 7-8 & $10,000 \mu \mathrm{g}(50 \mu \mathrm{g} / \mathrm{mL}$ and $200 \mathrm{ml})$ \\
Days 9-15 & $12,000 \mu \mathrm{g}(50 \mu \mathrm{g} / \mathrm{mL}$ and $240 \mathrm{ml})$ \\
Maintenance every 15 days & $12,000 \mu \mathrm{gg}(50 \mu \mathrm{g} / \mathrm{mL}$ and $240 \mathrm{ml})$ \\
\hline
\end{tabular}

The parameters evaluated were: Ag HBs, Anti-HBs, HVB viral load and transaminases, before starting the treatment, at 15 days of completion, at 6 months and 1 year.

We considered the qualitative result of the serological markers Ag HBs, AntiHBs (positive/negative).

The real-time PCR reference values were taken into account as a standardized method to determine the Viral Load with an analytical range of 40-20,000 IU / mL HBV DNA / Less than 1.6 - $7.3 \mathrm{log} 10 \mathrm{lU} / \mathrm{mL}$ HVB DNA. 
The values of biochemical markers (TGP) and (TGO) less than or equal to $40 \mathrm{ID} / \mathrm{L}$ were taken into account according to the reference values of the laboratory where the tests were performed.

Statistical analysis: We used SPSS 19.0 statistic software and we categorized the values using contingency tables utility and chi-square analysis for the significance on the changes before and after the treatment. Values of chi-square under 0,05 were considered significant.

\section{Results and discussion}

The anti-hepatitis B surface antigen (Ag HBs), formerly known as "Australian antigen" is the most important serological marker, appears in the serum 1 to 10 weeks after acute exposure to HBV, before the onset of symptoms or elevation of aminotransferases. Its persistence for more than 6 months implies chronic infection and its loss is a desirable objective followed by the appearance of Anti-HBs in the majority of patients [12].

Of the 28 patients with a positive HBsAg serological marker before starting treatment, $100 \%$ were negativized per month, maintaining these results at 6 months and a year in the total sample (Table 2). This process suggests that the immune response to autohemotherapy was favorable, although it is unable to eradicate the virus, tends to decrease the progression of the infection. It has to be considered that, the method used for this marker was qualitative and only provides information on the total antibody response to Anti-HBs. These results could be related to the use of ozone concentration of $50 \mu \mathrm{g} / \mathrm{mL}$ in doses reaching $12,000 \mu \mathrm{g}$ during the maintenance therapy that was able to modulate the release of cytokines, determinant for synthesis of these antibodies, coinciding with studies that have already demonstrated that high ozone concentrations (50 to $80 \mu \mathrm{g} / \mathrm{mL}$ ) are capable of modulating the release of these cytokines, as expression of different biological functions [13].

Table 2: Behavior of serological markers (Ag HBs, Anti-HBs) in 28 patients during one year of ozone treatment by major autohemotherapy.

\begin{tabular}{|c|c|c|c|c|}
\hline \multirow{2}{*}{$\begin{array}{c}\text { Serological } \\
\text { Markers }\end{array}$} & $\begin{array}{c}\text { Before starting } \\
\text { treatment }\end{array}$ & 1 month & 6 months & 1 year \\
\hline Ag HBs + & $28(100 \%)$ & 0 & 0 & 0 \\
\hline Ag HBs - & 0 & $28(100 \%)^{*}$ & $28(100 \%)^{*}$ & $28(100 \%)^{*}$ \\
\hline Anti-HBs + & 0 & $28(100 \%)^{*}$ & $28(100 \%)^{*}$ & $28(100 \%)^{*}$ \\
\hline Anti-HBs - & $28(100 \%)$ & 0 & 0 & 0 \\
\hline
\end{tabular}

*chi-square significant value.

The goal of HBV therapy is the suppression of virus replication to prevent disease progression; it should be aimed at maintaining the lowest possible title of HBV DNA.

When analyzing the viral load behavior before starting the treatment, most 
of the patients (57.1\%) presented viral load between 10,000-20,000 IU/mL. At one month the viral load was undetectable in $100 \%$ of the patients, maintaining this level during the year under treatment (Table 3). The results obtained can be compared with similar previous work reported by Jiao XJ et al in 2008 and Neronov in 2009 [14,15].

Table 3: Viral load behavior in 28 patients with ozone by major autohemotherapy during one year of treatment.

\begin{tabular}{|c|c|c|c|c|}
\hline Molecular Marker & \multicolumn{4}{|c|}{ Patients Number } \\
\hline $\begin{array}{c}\text { Viral Load (HBV- } \\
\text { DNA) IU/mL }\end{array}$ & $\begin{array}{c}\text { Before starting } \\
\text { treatment }\end{array}$ & 1 month & 6 months & 1year \\
\hline Undetectable & $0(0 \%)$ & $28(100 \%)^{*}$ & $28(100 \%)^{*}$ & $28(100 \%)^{*}$ \\
\hline $40-10,000$ & $12(29.6 \%)$ & 0 & 0 & 0 \\
\hline $10,000-20,000$ & $16(57.1 \%)$ & 0 & 0 & 0 \\
\hline
\end{tabular}

${ }^{*}$ chi-square significant value.

It is necessary to point out that, 15 days after the conclusion of ozone cycle by major autohemotherapy, a good response of the immune system was observed, maintained in a sustained way. This could be explained by the cumulative effects of the active metabolites produced during the ozone therapy that stimulates different pathways which ultimately result in an immune stimulation.

Ozone is considered by several authors as a drug capable of modifying the biological response by the multiplicity of action and the generation of intermolecular signalizations $[14,15,16]$.

The transaminases or aminotransferases are enzymes present inside the cells of our body, being responsible for the metabolism of some proteins. They are present in several body cells and in great quantity in the hepatocytes (liver cells). Whenever a cell that contains TGO or TGP suffers an injury, these enzymes "pour" into the blood, increasing their blood concentration. Therefore, it is easy to understand why liver diseases, which cause hepatocyte injury, occur with elevated blood levels of them, as may occur in the course of hepatitis.

In this study, the behavior of biochemical markers was analyzed (Table 4).

Table 4: Behavior of different biochemical markers in 28 patients treated with ozone by major autohemotherapy during one year.

\begin{tabular}{|c|c|c|c|c|}
\hline $\begin{array}{c}\text { Biochemical } \\
\text { markers }\end{array}$ & \multicolumn{4}{|c|}{ Patients Number } \\
\hline $\begin{array}{c}\text { TGO and TGP } \\
\text { (IU/L) }\end{array}$ & $\begin{array}{c}\text { Before starting } \\
\text { treatment }\end{array}$ & 1 month & 6 months & 1 year \\
\hline$<40$ & 0 & $28(100 \%)^{*}$ & $28(100 \%)^{*}$ & $28(100 \%)^{*}$ \\
\hline $40-100$ & $28(100 \%)$ & 0 & 0 & 0 \\
\hline
\end{tabular}

${ }^{*}$ chi-square significant value. 
Before initiating treatment, $100 \%$ of the patients had elevated transaminase levels (TGP and TGO) between 40-100 IU/L. At one month, $100 \%$ of the sample had normal values $(<40 \mathrm{Uds} / \mathrm{L})$, remaining at 6 months and one year of treatment, which is closely related to the decrease in viral load observed and the effects caused by ozone when stabilizing the cellular redox equilibrium.

\section{Conclusions}

Ozone therapy by major autohemotherapy has a stimulatory effect on the humoral response to the surface antigen of the Hepatitis B virus, as well as on the biochemical markers. The evaluation of the viral load, at different times of the therapy, was a marker of effectiveness to evaluate the persistence of the organism positive response to the ozone treatment by major autohemotherapy. No side effects were found during the study.

\section{References}

1. WHO. Global health sector strategy on viral hepatitis 2016-2021. Genève: WHO; 2016. Available from: https://apps.who.int/iris/bitstream/ handle/10665/246177/WHO-HIV0-2016.06-eng.pdf

2. WHO. Global hepatitis report 2017. Geneve: WHO; 2017. Available from: h t t p s: // a p p . who.int/iris/bitstream/handle/ 10665/255016/9789241565455-eng.pdf

3. Zoulim F, Locarnini S. Hepatitis B virus resistance to nucleoside analogues. Gastroenterology. 2009;137(5):1593-1608. doi: 10.1053/ j.gastro.2009.08.063.

4. Robinson WS, Clayton DA, Greenman RL. DNA of a human hepatitis E virus candidate. J Virol. 1975;14:384-391. PubMed PMID: 4847328.

5. Oh IS, Park SH. Immune-mediated liver injury in hepatitis B virus infection. Immune network. 2015;15(4):191-198. doi: 10.4110/in. 2015.15.4.191.

6. Vicente-Peña E. Medicina Interna. Diagnóstico y Tratamiento. 2 ed. La Habana: Editorial Ciencias Médicas; 2016.

7. Zaky S, Kamel SE, Hassan MS, Sallam NA, Shahata MA, Helal SR, et al. Preliminary results of ozone therapy as a possible treatment for patients with chronic hepatitis C. J Altern Complement Med. 2011;17(3):259-63. doi: 10.1089/acm.2010.0016.

8. Turkmen A, Kesice S, Elmali N, Cangir CC, Cakirguz M. Chronic B hepatitis and ozonotherapy. Journal of Case Reports in Practice. 2015;3(2):38-39.

9. Abba AK. Activation of lymphocytes. In: Cellular and Molecular Immunology. Abba AK, Lichtman A, editors. 7 ed. New York: WB Saunders Co; 2011. p. 203-224.

10. Díaz J, Martín N, Menéndez CS. Evaluación de la actividad inmunomoduladora del ozono sobre los leucocitos: in vivo e in vitro. Vaccimonitor. 2011;20(1):22-3.

11. Bocci V. Scientific and medical aspects of ozone therapy. State of the art. Arch Med Res. 2006;37:425-435. doi: 10.1016/j.arcmed. 2005.08.006.

12. Piscoya A, Cedron H, Tangel M. Hepatitis B. Diagnostico. 2007;46(1):1. 
13. Zamora Z, Borrego A. La mezcla gaseosa ozono-oxígeno incrementa la respuesta humoral contra el antígeno recombinante de superficie del virus de la hepatitis B en ratones. Revista CENIC Ciencias Biológicas. 2002;33(2):55-57.

14. Neronov VA. Experience with the use of ozone for the treatment of chronic viral hepatitis. Vopr Kurortol Fizioter Lech Fiz Kult. 2009;6:14-17.

15. Jiao XJ, Peng X. Clinilal study of medical ozone therapy in chronic hepatitis B of 20 patients. Zhonghua Shi Yan He Lin Chuang Bing Du Xue Za Zhi. 2008;22(6):484-5.

16. Gu XB, Yang XJ, Zhu HY, Xu YQ, Liu XY. Effect of medical ozone therapy on renal blood flow and renal function of patients with chronicsevere hepatitis. Chin Med J (Engl). 2010;123(18):2510-2513. 